$A \cap L \mid E R-36099$

\title{
Report of Extended Monitoring Studies for the Agenda, Kansas, Former CCC/USDA Site
}

\section{Environmental \\ Research Division}

Argonne National Laboratory

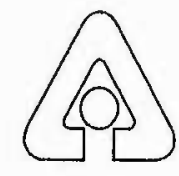

Operated by The University of Chicago, under Contract W-31-109-Eng-38, for the

United States Department of Energy 


\section{Report of Extended Monitoring Studies for the Agenda, Kansas, Former CCC/USDA Site}

Applied Geosciences and Environmental Management Section, Environmental Research Division,

Argonne National Laboratory, 9700 South Cass Avenue, Argonne, Illinois 60439

August 1999

Work sponsored by Commodity Credit Corporation, United States Department of Agriculture 


\section{Contents}

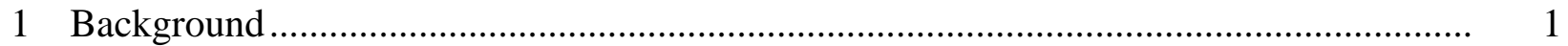

2 Extended Monitoring Program and Results............................................................ 2

$2.1 \quad$ Water Level Monitoring Results.................................................................. 2

2.2 Groundwater Analysis Results........................................................................... 3

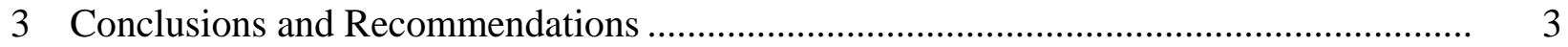

Appendix A: Quality Control for Monitoring at Agenda ........................................... 20

\section{Figures}

1 Map of Agenda, Kansas, Showing Locations of Wells in the Shallow Aquifer and Results of Analyses for Carbon Tetrachloride on Samples Collected from Those Wells during the Phase I and Phase II Investigations

2 Map of Agenda, Kansas, Showing Locations of Wells in the Deep Aquifer and Results of Analyses for Carbon Tetrachloride on Samples Collected from Those Wells during the Phase I and Phase II Investigations.

3 Hydrographs Showing Water Levels in the Deep-Aquifer Wells at Agenda during 1996.7

4 Hydrographs Showing Water Levels in the Deep-Aquifer Wells at Agenda during 1997.8

5 Hydrographs Showing Water Levels in the Deep-Aquifer Wells at Agenda during 1998.99

6 Hydrographs Showing Water Levels in the Deep-Aquifer Wells at Agenda during 1999.10

7 Map of Agenda, Kansas, Showing Water Levels in the Deep Aquifer on

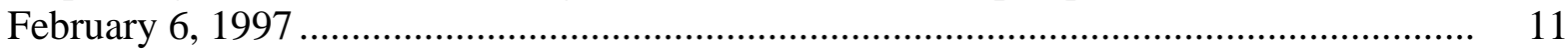

8 Map of Agenda, Kansas, Showing Water Levels in the Deep Aquifer on July 14, $1998 .$.

9 Map of Agenda, Kansas, Showing Water Levels in the Deep Aquifer on May 14, 1999.

10 Map of Agenda, Kansas, Showing Results of Analyses for Carbon Tetrachloride on Groundwater Samples from Shallow-Aquifer Wells in July 1997 and June 1998........

11 Map of Agenda, Kansas, Showing Results of Analyses for Carbon Tetrachloride on Groundwater Samples from Deep-Aquifer Wells in July 1997 and June 1998. 


\section{Tables}

1 Groundwater Samples Collected during Annual Monitoring at Agenda, Kansas ............. 16

2 Results of Carbon Tetrachloride and Chloroform Analyses during Annual

Monitoring at Agenda, Kansas .............................................................................. 18

3 Results of Field Measurements Made during Annual Monitoring at Agenda, Kansas ...... 19 


\section{Report of Extended Monitoring Studies for the Agenda, Kansas, Former CCC/USDA Site}

\section{Background}

Routine screening performed by the Kansas Department of Health and Environment (KDHE) in 1987 and subsequent KDHE studies at Agenda, Kansas, identified carbon tetrachloride at concentrations above the maximum contaminant level (MCL) of $5 \mu \mathrm{g} / \mathrm{L}$ in groundwater. The contaminated samples were obtained from two public water supply wells and at the site of a former grain storage facility operated by the Commodity Credit Corporation of the U.S. Department of Agriculture (CCC/USDA). Because the contamination might be linked to historical use of carbon tetrachloride-based grain fumigants at the former CCC/USDA facility, the CCC/USDA conducted a site investigation to establish the extent of the carbon tetrachloride contamination at Agenda and to determine whether remedial action is required. The investigation was performed by the Environmental Research Division of Argonne National Laboratory, using Argonne's QuickSite ${ }^{\mathrm{SM}}$ Expedited Site Characterization methodology.

Phases I and II of the QuickSite ${ }^{\mathrm{SM}}$ studies demonstrated that the groundwater flow system underlying Agenda consists of two aquifer units (termed shallow and deep) that are hydraulically separated by intervening shales and siltstones. Groundwater flow toward the southeast was identified within the shallow (Pleistocene sand) aquifer. No carbon tetrachloride contamination was detected in this unit (see Figure 1) or within vadose zone soils beneath the former CCC/USDA facility, indicating that no residual source of carbon tetrachloride contamination exists in these zones. Low levels of carbon tetrachloride (maximum $65 \mu \mathrm{g} / \mathrm{L}$; see Figure 2) were detected within the deep (Cretaceous sandstone) aquifer in the restricted area between the former CCC/USDA site and public water supply wells PWS1 and PWS2. Groundwater level monitoring performed by Argonne indicated that previous routine pumping of these wells strongly controlled the local hydraulic gradients and groundwater flow patterns within the deep aquifer. The pumping provided both the principal driving force for southward migration and the mechanism for capture and extraction of the carbon tetrachloride contamination within the deep aquifer.

Pumping of the municipal supply wells ended when the village distribution system was connected to the Republic County Rural Water District 2 in late 1996. Limited groundwater level monitoring conducted during Phase II of the QuickSite ${ }^{\mathrm{SM}}$ investigations suggested that, in the 
absence of municipal well pumping, ambient groundwater flow within the deep aquifer was toward the south-southwest under a very weak hydraulic gradient, resulting in nearly stagnant conditions. Insufficient data were available at that time, however, to estimate the potential longer-term character of groundwater flow and the contaminant migration conditions within the deep aquifer and hence the potential need for remedial action at the Agenda site.

\section{Extended Monitoring Program and Results}

To address the uncertainties described above, Argonne has continuously monitored water levels at five locations (MW1D, MW2D, MW3D, SB01, SB11; see Figure 2) within the deep aquifer at the Agenda site since mid 1996. Water levels were measured by using pressure transducers connected to automatic data loggers. Groundwater sampling for analyses for volatile organic compounds was also performed in these deep-aquifer wells and in shallow-aquifer wells MW1S, MW2S, MW3S, and SB12 (see Figure 1) during July 1997 and June 1998 to identify possible changes in the distribution of carbon tetrachloride within the aquifer system during the extended monitoring period. The results of these investigations are presented below.

\subsection{Water Level Monitoring Results}

Water level data were obtained during the monitoring period to characterize the longerterm groundwater flow at the site in the absence of pumping of the former municipal wells. The resulting hydrographs from the five deep-aquifer monitoring wells, shown in Figures 3-6, however, reflect some technical difficulties encountered during the monitoring period. The 1997 and 1998 records for wells MW1D, MW2D, and MW3D have intervals of missing data because of a computer malfunction during the downloading of data from these loggers. The hydrograph for well SB11 contains several intervals of erratic transducer response, resulting from electronic interference of unknown origin that affected the calibration of this data logger. In addition, inspection of the hydrographs for wells MW1D and SB11 shows that the "polarity" of the barometric pressure response (the small-scale oscillations) becomes reversed in several portions of the records for these wells, probably because of blockage of the transducer vent tube. The underlying water level trends shown by these portions of the records are, however, entirely consistent with the trends in records for the other wells monitored at the site. 
Figures 3-6 show that absolute water levels within the deep aquifer stabilized relatively quickly following the cessation of pumping in 1996, varying seasonally by a maximum of approximately $3 \mathrm{ft}$ during the monitoring period. The hydrographs further demonstrate that relative water levels between monitoring wells, and hence apparent hydraulic gradients and flow directions, have remained fairly consistent across the study area, as shown in Figures 7-9 for February 1997, July 1998, and May 1999, respectively. Under the observed conditions, average linear groundwater velocities of only 2-20 ft/yr toward the south-southwest can be estimated from aquifer parameter data obtained during the Phase II studies.

\subsection{Groundwater Analysis Results}

Sampling details and analytical results for volatile organic compounds in groundwater samples collected from the shallow and deep aquifers during July 1997 and June 1998 are presented in Tables 1-3. (A discussion of quality control activities accompanying these analyses is in Appendix A.) Measured carbon tetrachloride concentrations for these samples are depicted in Figures 10-11. Carbon tetrachloride contamination was not detected in any of the groundwater samples recovered from the shallow aquifer. Measured carbon tetrachloride concentrations for samples collected from the deep aquifer were effectively identical to those obtained during the Phase II investigations in 1996, except for groundwater from well MW1D. The analyses for this well showed an apparent decrease in concentrations during the monitoring period.

\section{Conclusions and Recommendations}

The extended monitoring studies confirmed that groundwater within the deep aquifer at Agenda has been relatively stagnant since pumping of the former public water supply wells at the southern edge of the village ended in 1996. Regular future use of these wells is not expected, because the village is now permanently connected to a rural water supply.

No carbon tetrachloride contamination has been detected in the shallow aquifer or within vadose zone soils beneath the former CCC/USDA facility, indicating that no residual source of carbon tetrachloride contamination exists in these zones. Groundwater carbon tetrachloride concentrations exceeding the MCL were identified at only one location, monitoring well MW1D, in the deep aquifer. This contamination poses no health threat to the village population, which is now served by the Republic County Rural Water District 2. 
The nearest potential residence downgradient of the village that might be served by a private well penetrating the deep aquifer lies at least 1,000 ft southwest of well MW1D. An average linear groundwater flow velocity of only 2-20 ft/yr toward the south-southwest was calculated for the deep aquifer under the present ambient hydraulic gradient. Under these conditions, an estimated minimum of $50 \mathrm{yr}$ would be required for migration of the existing contaminated groundwater over this distance, assuming no retardation of carbon tetrachloride within the aquifer. The observed groundwater contamination therefore poses no future health threat to any existing residents along the predicted downgradient pathway within the next 50 years.

On the basis of these findings, Argonne recommends that continuing the present annual monitoring (water levels and annual groundwater sampling) of the Agenda aquifer system, or investigating potential aquifer restoration scenarios for this site, is technically unwarranted. However, Argonne does recommend that one more round of samples be collected in 1999 from wells MW1D, PWS1 (if accessible), and SB11. In addition, the downgradient private residence noted above will be investigated, and a groundwater sample will be collected if a deep-aquifer well is found to be present. The sampling results will be provided in a subsequent letter report. 


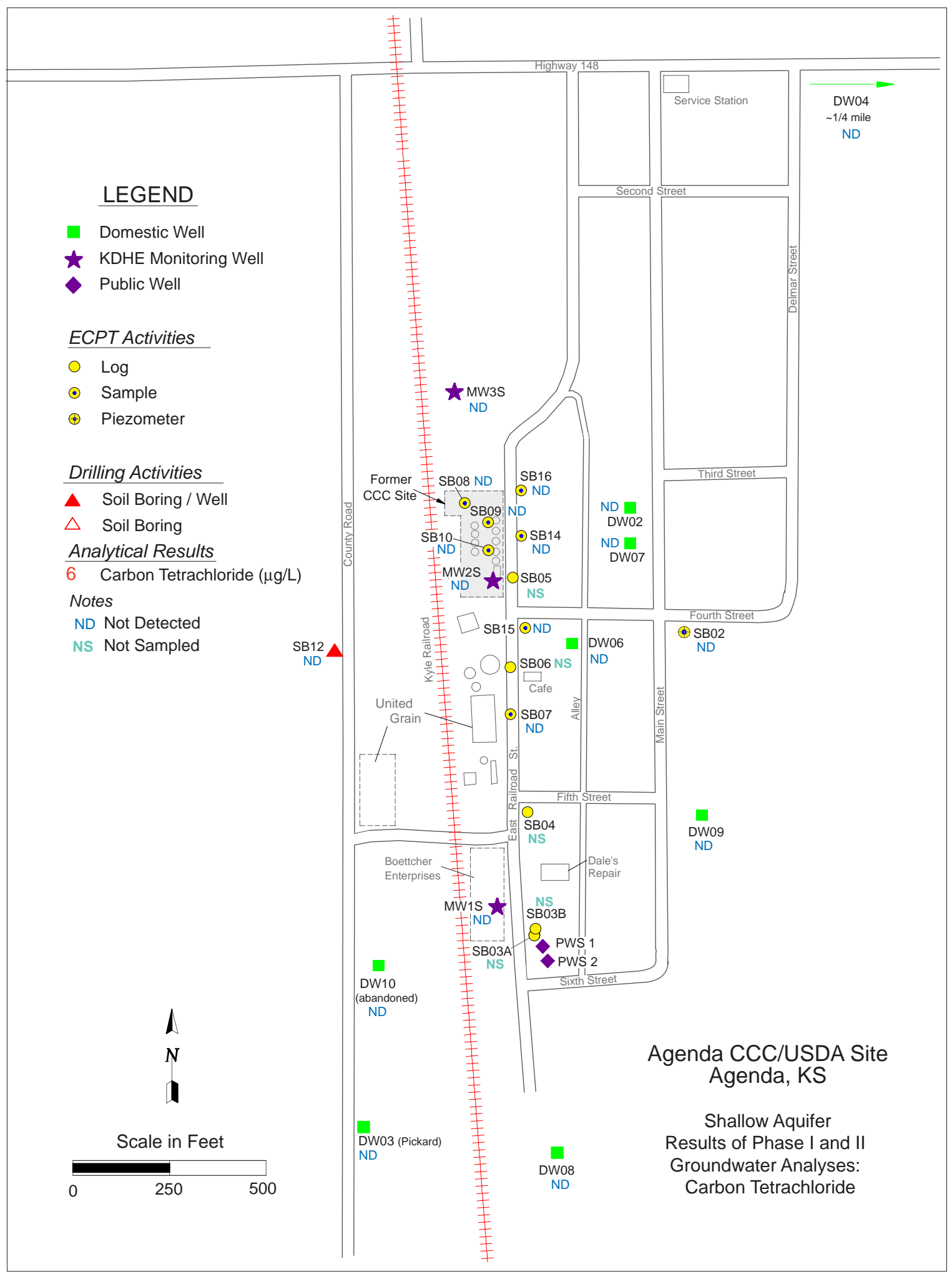

FIGURE 1 Map of Agenda, Kansas, Showing Locations of Wells in the Shallow Aquifer and Results of Analyses for Carbon Tetrachloride on Samples Collected from Those Wells during the Phase I and Phase II Investigations 


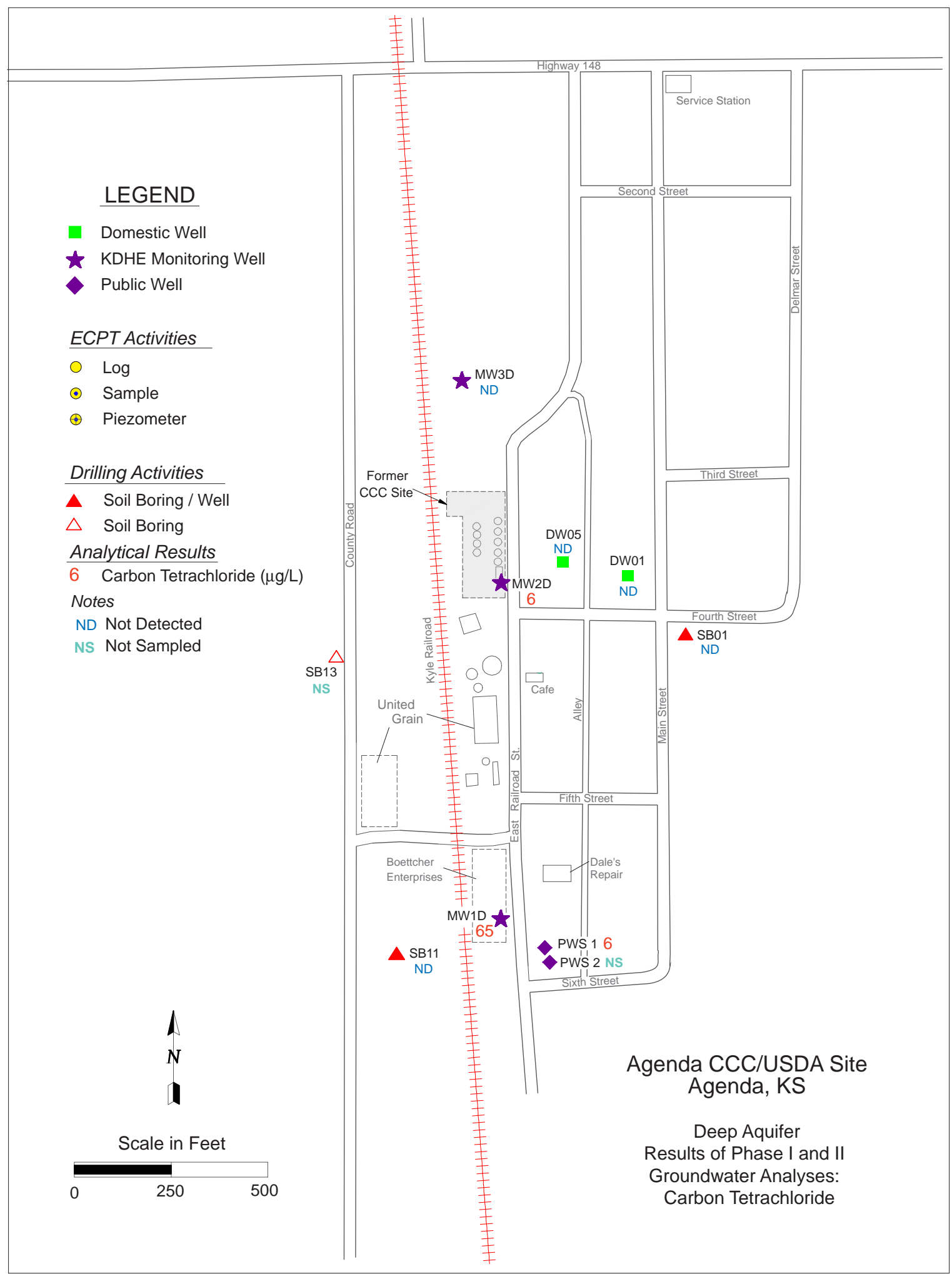

FIGURE 2 Map of Agenda, Kansas, Showing Locations of Wells in the Deep Aquifer and Results of Analyses for Carbon Tetrachloride on Samples Collected from Those Wells during the Phase I and Phase II Investigations 


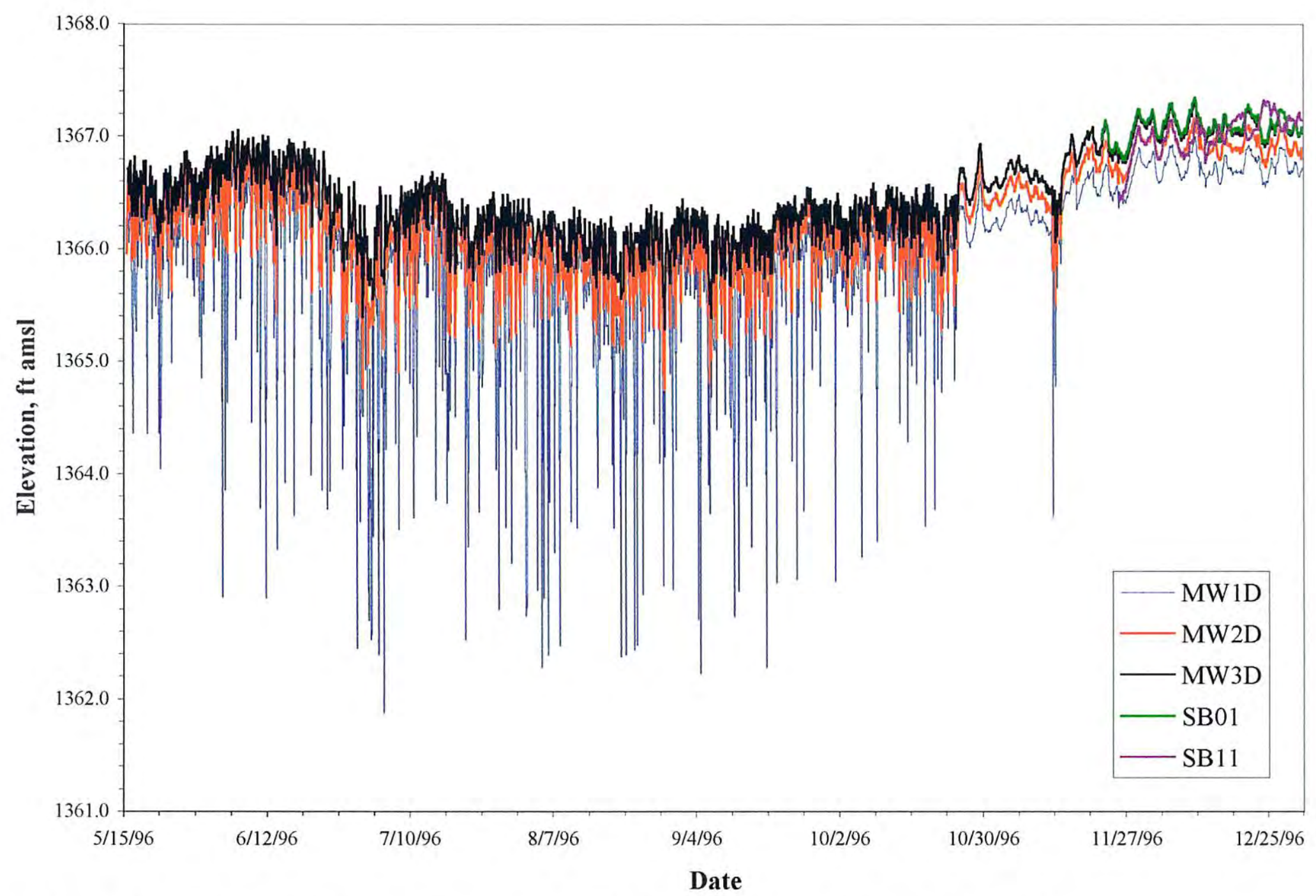

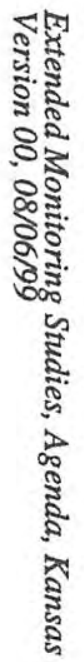

FIGURE 3 Hydrographs Showing Water Levels in the Deep-Aquifer Wells at Agenda during 1996 


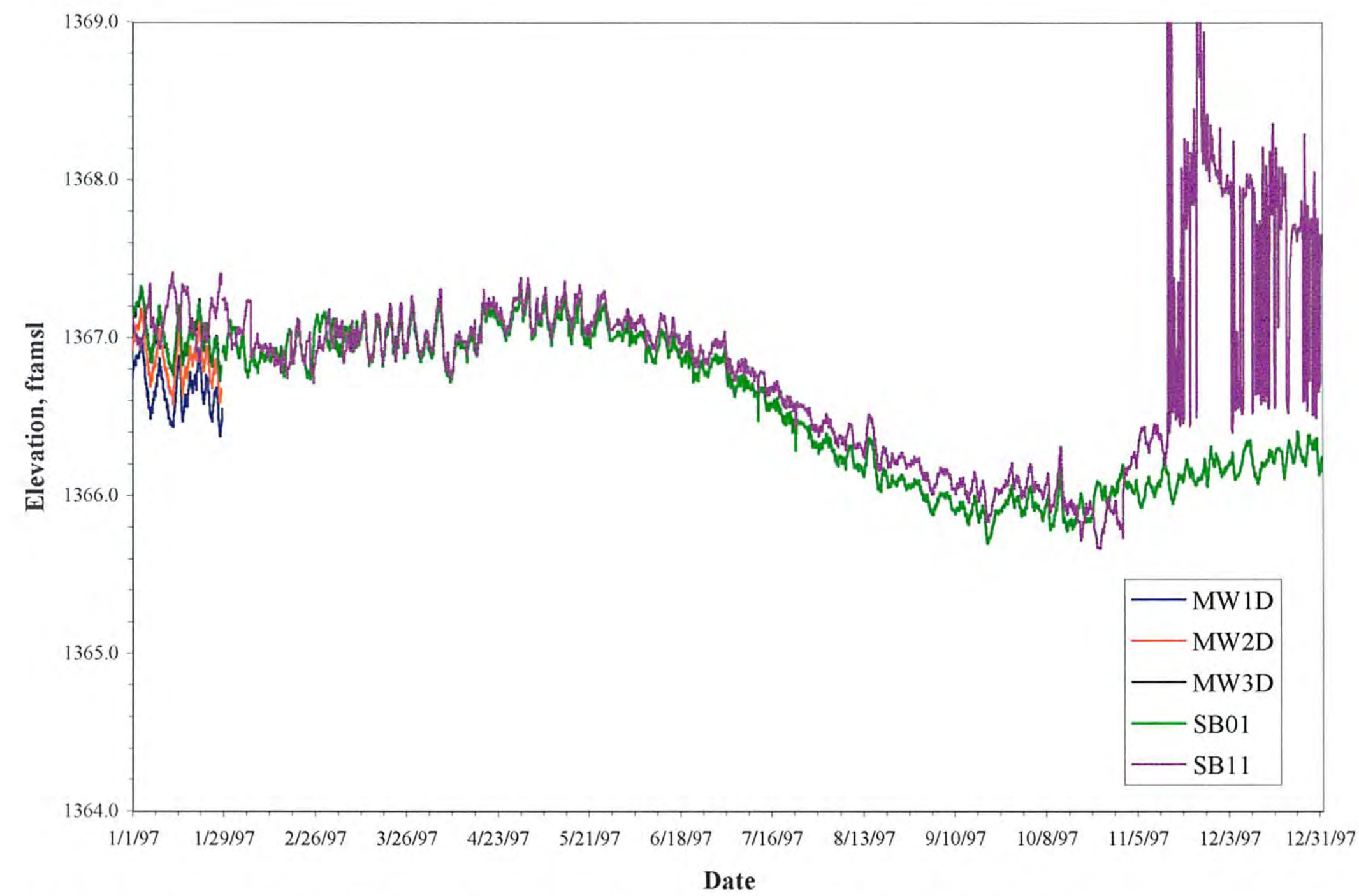

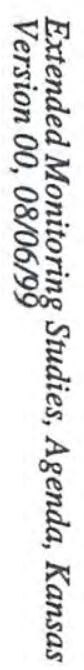

FIGURE 4 Hydrographs Showing Water Levels in the Deep-Aquifer Wells at Agenda during 1997 


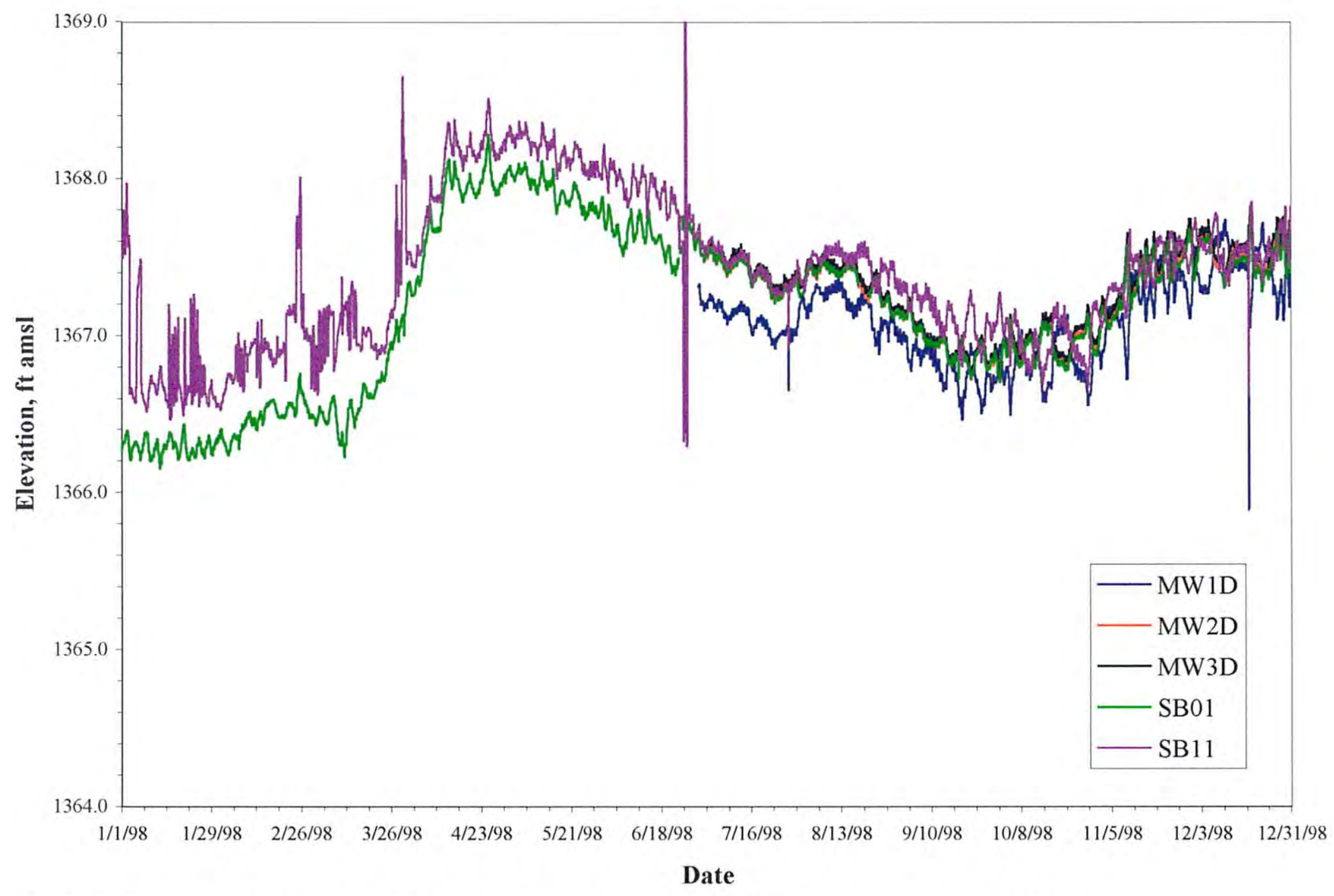

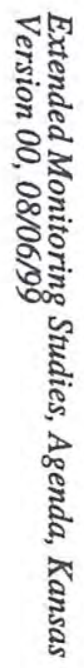

FIGURE 5 Hydrographs Showing Water Levels in the Deep-Aquifer Wells at Agenda during 1998 


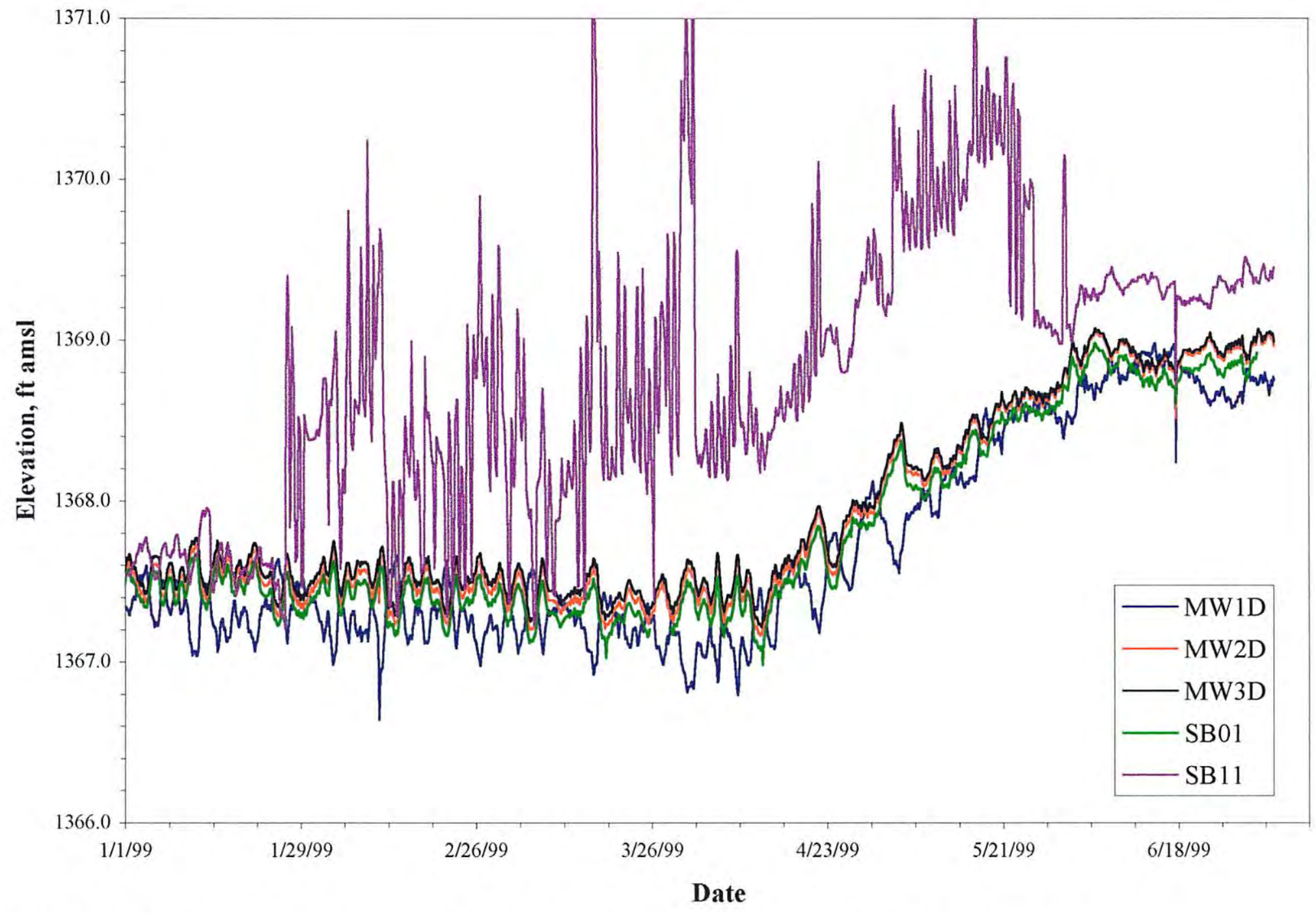

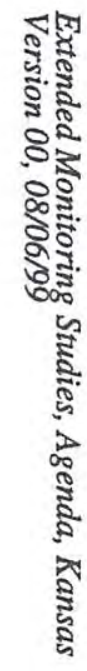

FIGURE 6 Hydrographs Showing Water Levels in the Deep-Aquifer Wells at Agenda during 1999 


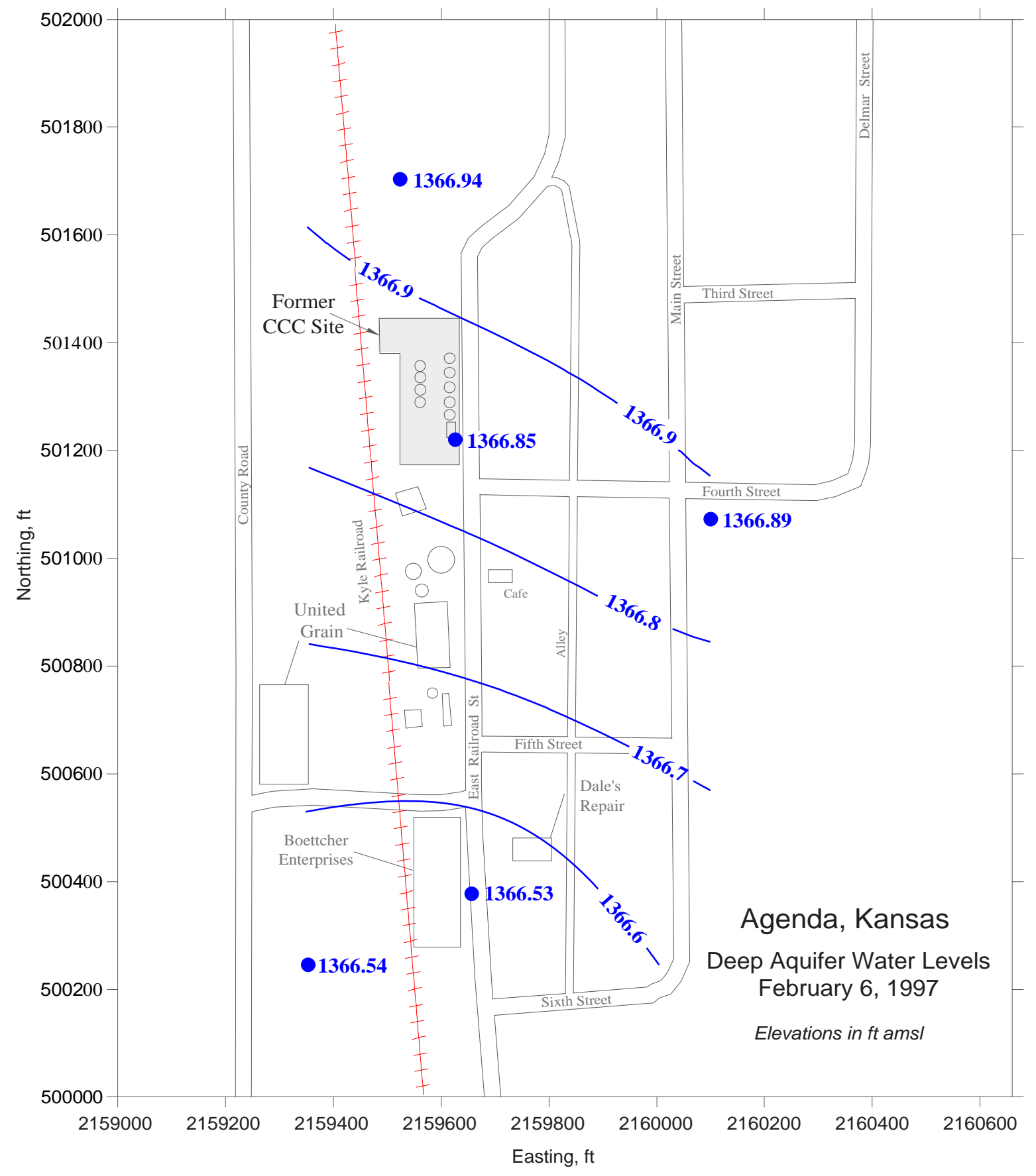

FIGURE 7 Map of Agenda, Kansas, Showing Water Levels in the Deep Aquifer on February 6, 1997 


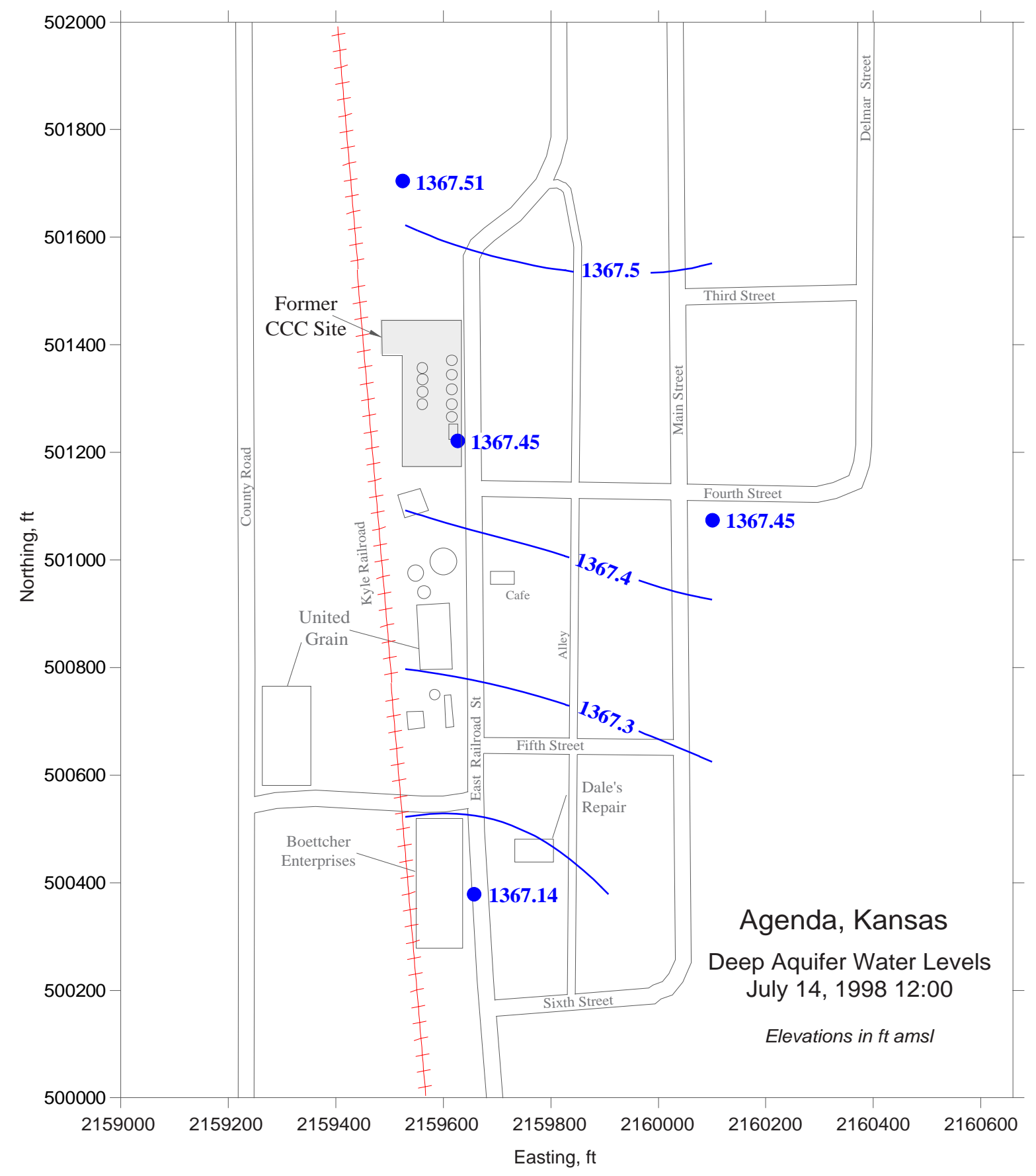

FIGURE 8 Map of Agenda, Kansas, Showing Water Levels in the Deep Aquifer on July 14, 1998 


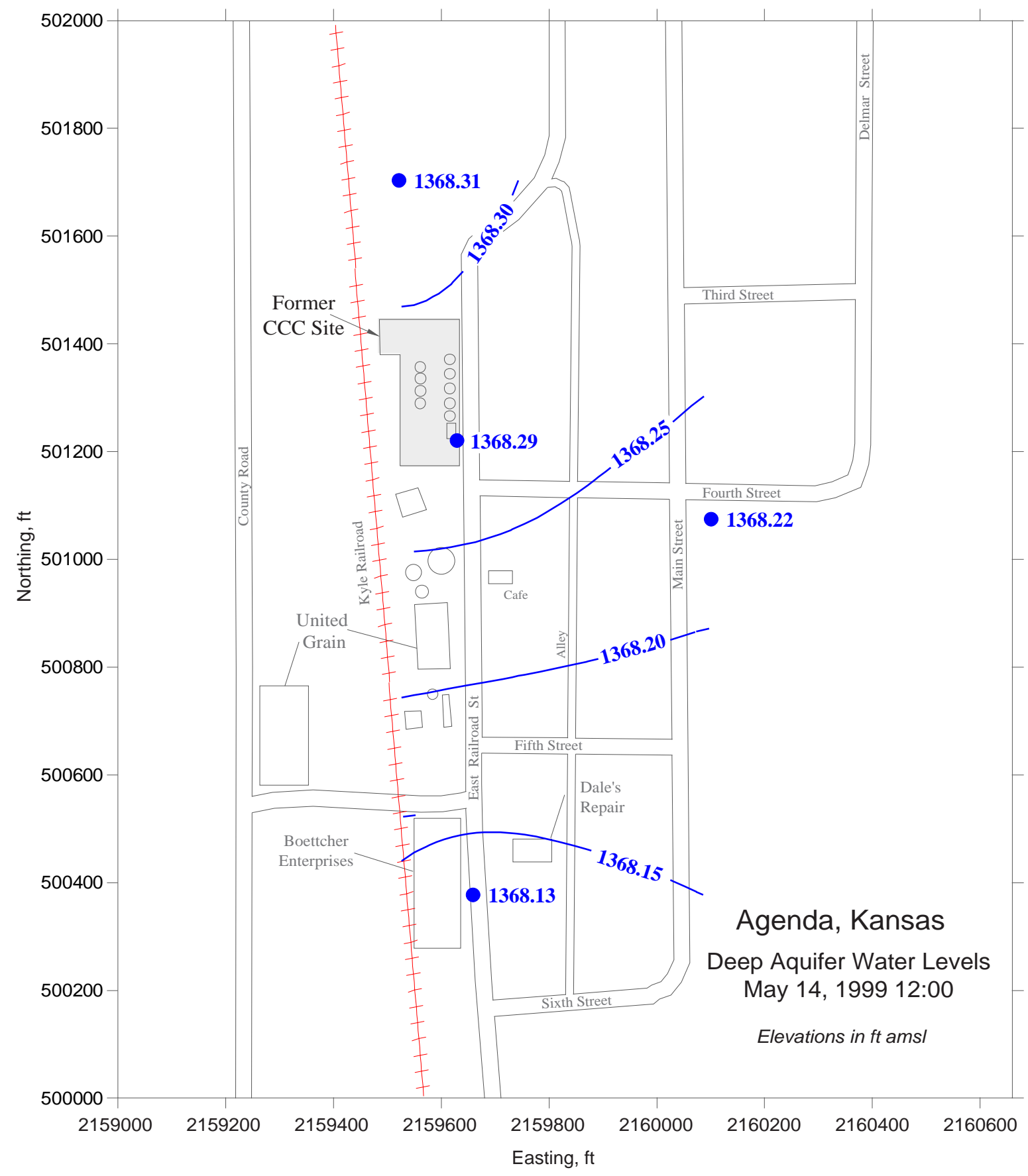

FIGURE 9 Map of Agenda, Kansas, Showing Water Levels in the Deep Aquifer on May 14, 1999 


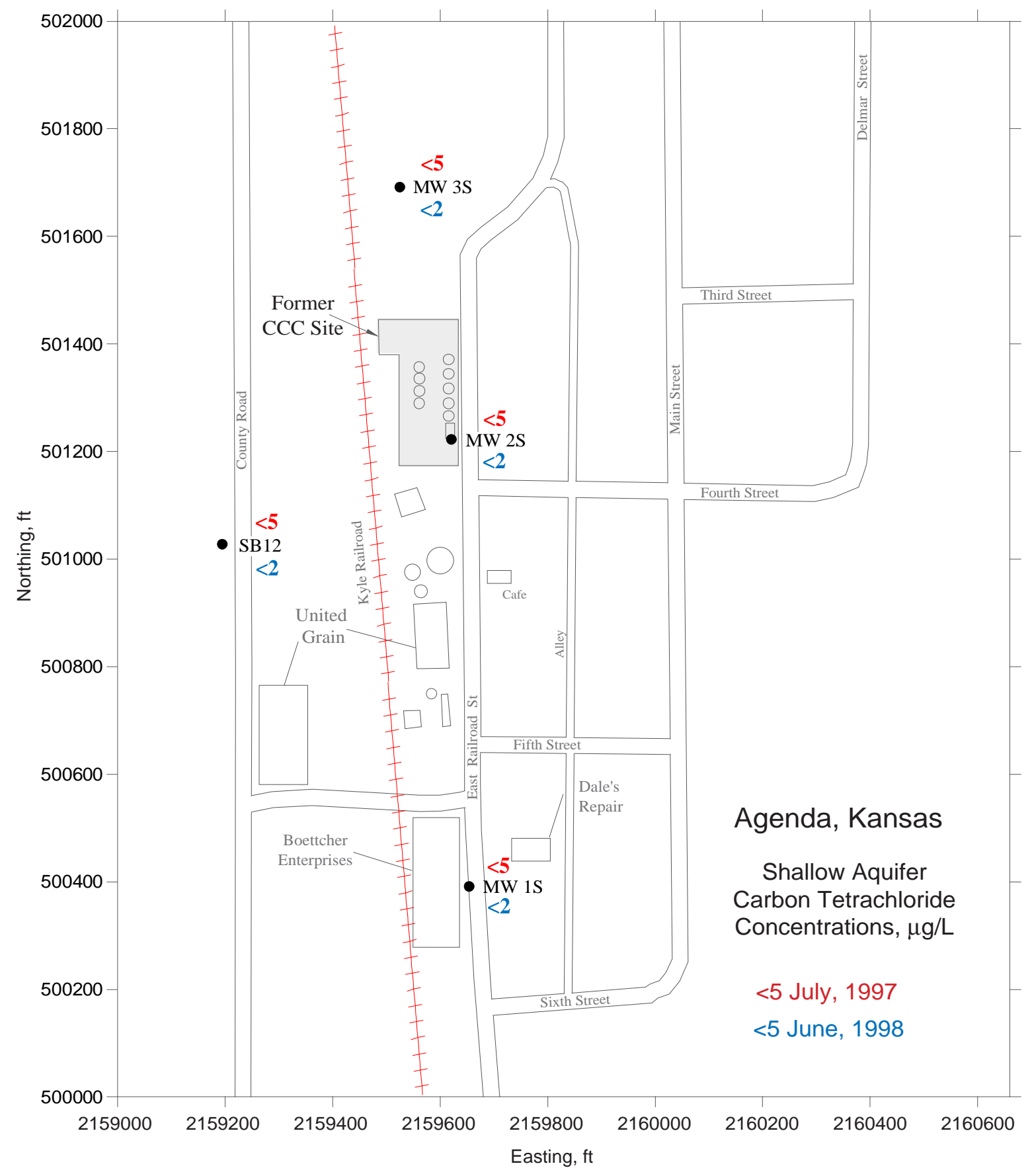

FIGURE 10 Map of Agenda, Kansas, Showing Results of Analyses for Carbon Tetrachloride on Groundwater Samples from Shallow-Aquifer Wells in July 1997 and June 1998 


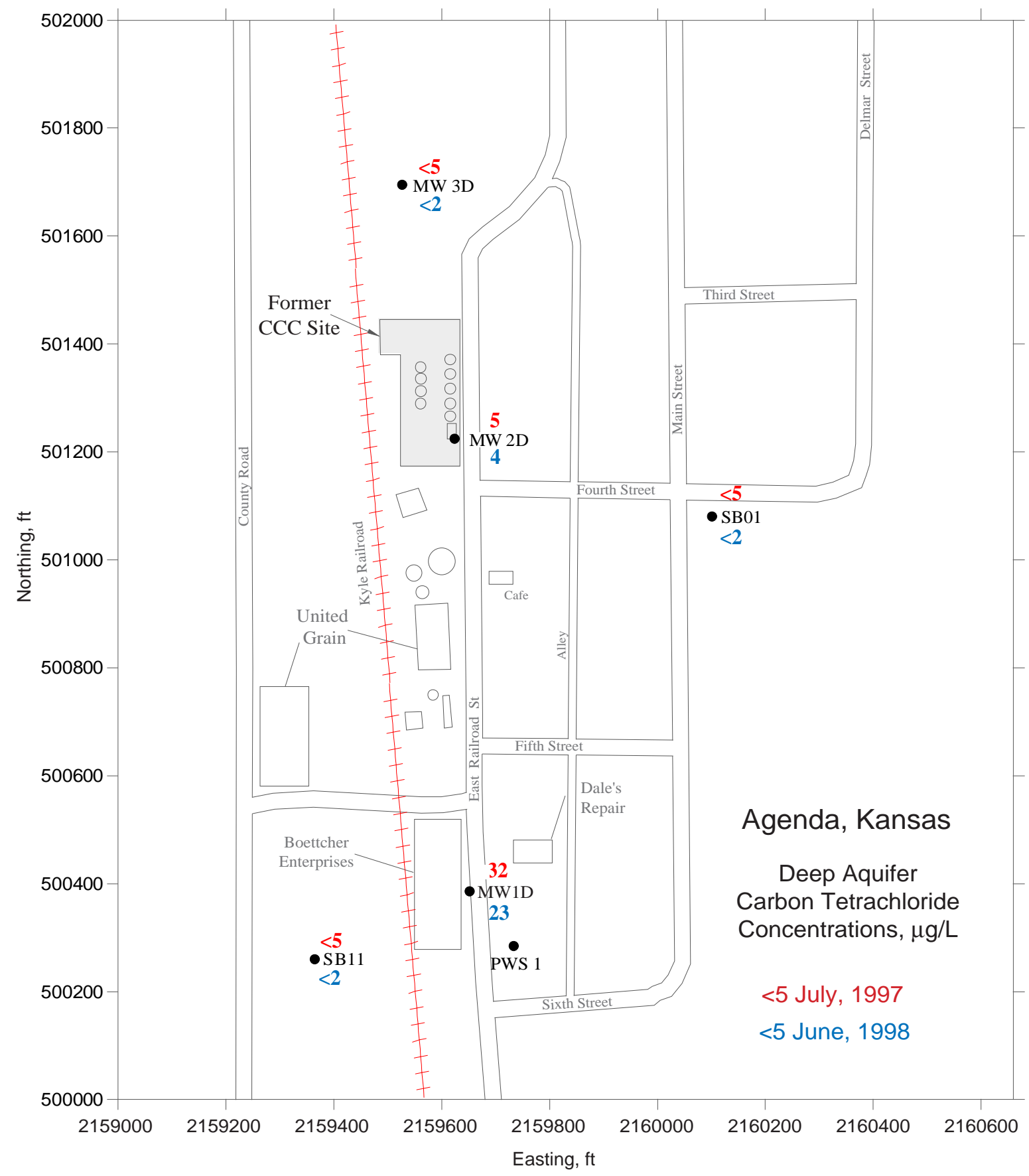

FIGURE 11 Map of Agenda, Kansas, Showing Results of Analyses for Carbon Tetrachloride on Groundwater Samples from Deep-Aquifer Wells in July 1997 and June 1998 
TABLE 1 Groundwater Samples Collected during Annual Monitoring at Agenda, Kansas

\begin{tabular}{|c|c|c|c|c|}
\hline Location & Sample & $\begin{array}{l}\text { Depth } \\
(\mathrm{ft})\end{array}$ & $\begin{array}{l}\text { Sample } \\
\text { Date }\end{array}$ & Sample Description \\
\hline \multicolumn{5}{|c|}{ July 1997 Monitoring } \\
\hline MW1S & ANMW01S-W-04982 & $44-54$ & $7 / 23 / 97$ & $\begin{array}{l}\text { Sample collected after purging of } 35 \mathrm{gal} \text { at } 1.25 \mathrm{gpm} \text {. Depth to water from top of } \\
\text { casing }(\mathrm{TOC})=42.10 \mathrm{ft} \text {. Depth of well from TOC }=54.20 \mathrm{ft} \text {. Purge pump set } 3 \mathrm{ft} \\
\text { from bottom of well. }\end{array}$ \\
\hline MW1D & ANMW01D-W-04980 & $130-140$ & $7 / 23 / 97$ & $\begin{array}{l}\text { Sample collected after purging of } 245 \mathrm{gal} \text { at } 2.5 \mathrm{gpm} \text {. Depth to water from TOC = } \\
47.91 \mathrm{ft} \text {. Depth of well from TOC }=141.20 \mathrm{ft} \text {. Purge pump set } 3 \mathrm{ft} \text { from bottom. }\end{array}$ \\
\hline MW2S & ANMW02S-W-04978 & $49-59$ & $7 / 23 / 97$ & $\begin{array}{l}\text { Sample collected after purging of } 187 \mathrm{gal} \text { at } 2.2 \mathrm{gpm} \text {. Depth to water from TOC }= \\
38.29 \mathrm{ft} \text {. Depth of well from TOC }=57 \mathrm{ft} \text {. Purge pump set } 3 \mathrm{ft} \text { from bottom. }\end{array}$ \\
\hline MW2D & ANMW02D-W-04979 & $129-139$ & $7 / 23 / 97$ & $\begin{array}{l}\text { Sample collected after purging of } 355 \text { gal. Depth to water from TOC }=45.8 \mathrm{ft} \text {. Depth of } \\
\text { well from TOC }=139.45 \mathrm{ft} \text {. Purge pump set at } 5 \mathrm{ft} \text { above bottom of well during purge } \\
\text { of } 330 \text { gal. Pump lowered to } 3 \mathrm{ft} \text { above bottom to purge final } 25 \text { gal. }\end{array}$ \\
\hline MW3S & ANMW03S-W-04974 & $38-48$ & $7 / 22 / 97$ & $\begin{array}{l}\text { Sample collected after purging of } 62.5 \mathrm{gal} \text { at } 2.5 \mathrm{gpm} \text {. Depth to water from TOC = } \\
24.68 \mathrm{ft} \text {. Depth of well from TOC }=48.13 \mathrm{ft} \text {. }\end{array}$ \\
\hline MW3D & ANMW03D-W-04975 & $104-114$ & $7 / 22 / 97$ & $\begin{array}{l}\text { Sample collected after purging of } 210 \mathrm{gal} \text { at } 2.1 \mathrm{gpm} \text {. Depth to water from TOC = } \\
33.13 \mathrm{ft} \text {. Depth of well from TOC }=116.20 \mathrm{ft} \text {. }\end{array}$ \\
\hline SB01 & ANSB01-W-04972 & 118.9-128.9 & $7 / 22 / 97$ & $\begin{array}{l}\text { Sample collected after purging of } 294 \mathrm{gal} \text { at } 14 \mathrm{gpm} \text {. Depth to water from TOC }=45.2 \\
\text { ft. Depth of well from TOC }=133.77 \mathrm{ft} \text {. Pump placed at approximately } 123 \mathrm{ft} \text {. Purged } \\
\text { to ditch. }\end{array}$ \\
\hline SB11 & ANSB11-W-04973 & $107-127$ & $7 / 22 / 97$ & $\begin{array}{l}\text { Sample collected after purging of } 250 \mathrm{gal} \text {. Depth to water from TOC }=34.63 \mathrm{ft} \text {. Depth } \\
\text { of well from TOC }=135.32 \mathrm{ft} \text {. Purged by using } \\
\text { two Redi-flow pumps set in tandem at } 3 \mathrm{ft} \text { and } 6 \mathrm{ft} \text { above the bottom of the well, each } \\
\text { pumping at about } 5 \mathrm{gpm} \text {. }\end{array}$ \\
\hline
\end{tabular}


TABLE 1 (Cont.)

\begin{tabular}{|c|c|c|c|c|}
\hline Location & Sample & $\begin{array}{l}\text { Depth } \\
\text { (ft) }\end{array}$ & $\begin{array}{l}\text { Sample } \\
\text { Date }\end{array}$ & Sample Description \\
\hline
\end{tabular}

July 1997 Monitoring (Cont.)

SB12

ANSB12-W-04976

$31.5-41.5$

$7 / 22 / 97$

Sample collected after purging of $107 \mathrm{gal}$ at $3 \mathrm{gpm}$, decreasing to $1 \mathrm{gpm}$. Depth to water from TOC $=24.41 \mathrm{ft}$. Depth of well from TOC $=46 \mathrm{ft}$. Pump set $3 \mathrm{ft}$ from bottom.

June 1998 Monitoring

\begin{tabular}{|c|c|c|c|c|}
\hline MW1S & ANMW01S-W-04990 & $44-54$ & $6 / 24 / 98$ & $\begin{array}{l}\text { Sample collected after purging of } 37 \mathrm{gal}(1.3 \mathrm{gpm} \text { for } 28 \mathrm{~min}) \text {. Depth to water from } \\
\text { TOC }=41.58 \mathrm{ft} \text {. Depth of well from TOC }=54.25 \mathrm{ft} \text {. }\end{array}$ \\
\hline MW1D & ANMW01D-W-04988 & $130-140$ & $6 / 24 / 98$ & $\begin{array}{l}\text { Sample collected after purging of } 270 \mathrm{gal}(10 \mathrm{gpm} \text { for } 27 \mathrm{~min}) \text {. Depth to water from } \\
\text { TOC }=46.72 \mathrm{ft} \text {. Depth of well from TOC }=141.25 \mathrm{ft} \text {. }\end{array}$ \\
\hline MW2S & ANMW02S-W-04991 & $49-59$ & $6 / 24 / 98$ & $\begin{array}{l}\text { Sample collected after purging of } 152 \mathrm{gal}(1.6 \mathrm{gpm} \text { for } 95 \mathrm{~min}) \text {. Depth to water from } \\
\text { TOC }=37.80 \mathrm{ft} \text {. Depth of well from TOC }=57.20 \mathrm{ft} \text {. }\end{array}$ \\
\hline MW2D & ANMW02D-W-04993 & $129-139$ & $6 / 24 / 98$ & $\begin{array}{l}\text { Sample collected after purging of } 384 \mathrm{gal}(8 \mathrm{gpm} \text { for } 48 \mathrm{~min}) \text {. Depth to water from TOC } \\
=46.73 \mathrm{ft} \text {. Depth of well }=139.30 \mathrm{ft} \text {. }\end{array}$ \\
\hline MW3S & ANMW03S-W-04995 & $38-48$ & $6 / 24 / 98$ & $\begin{array}{l}\text { Sample collected after purging of } 50 \mathrm{gal}(1.34 \mathrm{gpm} \text { for } 37 \mathrm{~min}) \text {. Depth to water from } \\
\mathrm{TOC}=23.61 \mathrm{ft} . \text { Depth of well from TOC }=48.19 \mathrm{ft} \text {. }\end{array}$ \\
\hline MW3D & ANMW03D-W-04994 & $104-114$ & $6 / 24 / 98$ & $\begin{array}{l}\text { Sample collected after purging of } 209 \mathrm{gal}(1.34 \mathrm{gpm} \text { for } 156 \mathrm{~min}) \text {. Depth to water from } \\
\text { TOC }=32.2 \mathrm{ft} \text {. Depth of well from TOC }=116.14 \mathrm{ft} \text {. }\end{array}$ \\
\hline SB01 & ANSB01-W-04987 & $118.9-128.9$ & $6 / 23 / 98$ & $\begin{array}{l}\text { Sample collected after purging of } 300 \mathrm{gal}(10 \mathrm{gpm} \text { for } 30 \mathrm{~min}) \text {. Depth to water from } \\
\text { TOC }=44.57 \mathrm{ft} . \text { Depth of well from TOC }=133.88 \mathrm{ft} \text {. }\end{array}$ \\
\hline SB11 & ANSB11-W-04996 & $107-127$ & $6 / 25 / 98$ & $\begin{array}{l}\text { Sample collected after purging of } 260 \mathrm{gal}(2 \mathrm{gpm} \text { for } 130 \mathrm{~min}) \text {. Depth to water from } \\
\text { TOC }=33.51 \mathrm{ft} . \text { Depth of well from TOC }=135.28 \mathrm{ft} \text {. }\end{array}$ \\
\hline SB12 & ANSB12-W-04986 & $31.5-41.5$ & $6 / 23 / 98$ & $\begin{array}{l}\text { Sample collected after purging of } 70 \mathrm{gal}(2 \mathrm{gpm} \text { for } 35 \mathrm{~min}) \text {. Depth to water from TOC } \\
=23.55 \mathrm{ft} \text {. Depth of well from TOC }=46.05 \mathrm{ft} \text {. }\end{array}$ \\
\hline
\end{tabular}


TABLE 2 Results of Carbon Tetrachloride and Chloroform Analyses during Annual Monitoring at Agenda, Kansas

\begin{tabular}{|c|c|c|c|c|c|c|c|}
\hline \multirow[b]{3}{*}{ Location } & \multirow[b]{3}{*}{ Sample } & \multirow{3}{*}{$\begin{array}{l}\text { Depth } \\
\text { (ft) }\end{array}$} & \multirow{3}{*}{$\begin{array}{l}\text { Sample } \\
\text { Date }\end{array}$} & \multicolumn{4}{|c|}{ Concentration $=\mu \mathrm{g} / \mathrm{L}$} \\
\hline & & & & \multicolumn{2}{|c|}{$\begin{array}{c}\text { Carbon } \\
\text { Tetrachloride }\end{array}$} & \multicolumn{2}{|c|}{ Chloroform } \\
\hline & & & & CLPa & AGEM & CLPa & AGEM \\
\hline \multicolumn{8}{|c|}{ July 1997 Monitoring } \\
\hline MW1S & ANMW01S-W-04982 & $44-54$ & $7 / 23 / 97$ & $<5$ & & $<5$ & \\
\hline MW1D & ANMW01D-W-04980 & $130-140$ & $7 / 23 / 97$ & 32 & 44 & $<5$ & $<2$ \\
\hline MW2S & ANMW02S-W-04978 & $49-59$ & 7/23/97 & $<5$ & & $<5$ & \\
\hline MW2D & ANMW02D-W-04979 & $129-139$ & $7 / 23 / 97$ & 5 & 6 & $<5$ & $<2$ \\
\hline MW3S & ANMW03S-W-04974 & $38-48$ & $7 / 22 / 97$ & $<5$ & & $<5$ & \\
\hline MW3D & ANMW03D-W-04975 & $104-114$ & $7 / 22 / 97$ & $<5$ & $<2$ & $<5$ & $<2$ \\
\hline SB01 & ANSB01-W-04972 & $118.9-128.9$ & $7 / 22 / 97$ & $<5$ & & $<5$ & \\
\hline SB11 & ANSB11-W-04973 & $107-127$ & $7 / 22 / 97$ & $<5$ & & $<5$ & \\
\hline SB12 & ANSB12-W-04976 & $31.5-41.5$ & $7 / 22 / 97$ & $<5$ & & $<5$ & \\
\hline \multicolumn{8}{|c|}{ June 1998 Monitoring } \\
\hline MW1S & ANMW01S-W-04990 & $44-54$ & $6 / 24 / 98$ & $<5$ & $<2$ & $<5$ & $<2$ \\
\hline MW1D & ANMW01D-W-04988 & $130-140$ & $6 / 24 / 98$ & 34 & 23 & $<5$ & $<2$ \\
\hline MW2S & ANMW02S-W-04991 & $49-59$ & $6 / 24 / 98$ & $<5$ & $<2$ & $<5$ & $<2$ \\
\hline MW2D & ANMW02D-W-04993 & $129-139$ & $6 / 24 / 98$ & & 4 & & $<2$ \\
\hline MW3S & ANMW03S-W-04995 & $38-48$ & $6 / 24 / 98$ & & $<2$ & & $<2$ \\
\hline MW3D & ANMW03D-W-04994 & $104-114$ & $6 / 24 / 98$ & $<5$ & $<2$ & $<5$ & $<2$ \\
\hline SB01 & ANSB01-W-04987 & $118.9-128.9$ & 6/23/98 & & $<2$ & & $<2$ \\
\hline SB11 & ANSB11-W-04996 & 107-127 & $6 / 25 / 98$ & & $<2$ & & $<2$ \\
\hline SB12 & ANSB12-W-04986 & $31.5-41.5$ & $6 / 23 / 98$ & & $<2$ & & $<2$ \\
\hline
\end{tabular}

a Analysis by Intertek Testing Services (Colchester, Vermont) in July 1997 and by Southwest Laboratory (Broken Arrow, Oklahoma) in June 1998. 
TABLE 3 Results of Field Measurements Made during Annual Monitoring at Agenda, Kansas

\begin{tabular}{|c|c|c|c|c|c|c|c|c|c|}
\hline \multirow[b]{2}{*}{ Location } & \multirow[b]{2}{*}{ Sample } & \multirow[b]{2}{*}{$\begin{array}{l}\text { Depth } \\
\text { (ft) }\end{array}$} & \multirow[b]{2}{*}{$\begin{array}{l}\text { Sample } \\
\text { Date }\end{array}$} & \multirow[b]{2}{*}{$\begin{array}{l}\text { Temperature } \\
\left({ }^{\circ} \mathrm{C}\right)\end{array}$} & \multirow[b]{2}{*}{$\mathrm{pH}$} & \multirow[b]{2}{*}{ Conductivity } & \multicolumn{3}{|c|}{ Concentration (mg/L) } \\
\hline & & & & & & & Alkalinity & $\begin{array}{l}\text { Dissolved } \\
\text { Oxygen }\end{array}$ & Nitrate \\
\hline \multicolumn{10}{|c|}{ July 1997 Monitoring } \\
\hline MW1S & ANMW01S-W-04982 & $44-54$ & $7 / 23 / 97$ & 18.2 & 6.85 & 1,322 & 350 & 3 & 10 \\
\hline MW1D & ANMW01D-W-04980 & $130-140$ & $7 / 23 / 97$ & 17.8 & 6.93 & 617 & 300 & 3 & $15-20$ \\
\hline MW2S & ANMW02S-W-04978 & 49-59 & $7 / 23 / 97$ & 16.6 & 6.80 & 1,261 & 350 & 0 & 25 \\
\hline MW2D & ANMW02D-W-04979 & $129-139$ & $7 / 23 / 97$ & 17.4 & 7.02 & 748 & 260 & 3 & 15 \\
\hline MW3S & ANMW03S-W-04974 & $38-48$ & $7 / 22 / 97$ & 15.3 & 6.83 & 858 & 250 & 3 & 15 \\
\hline MW3D & ANMW03D-W-04975 & $104-114$ & $7 / 22 / 97$ & 16.3 & 7.16 & 609 & 350 & 3 & 7.5 \\
\hline SB01 & ANSB01-W-04972 & 118.9-128.9 & $7 / 22 / 97$ & 14.5 & 7.15 & 522 & 300 & $5-6$ & 5 \\
\hline SB11 & ANSB11-W-04973 & $107-127$ & $7 / 22 / 97$ & 17.3 & 6.94 & 577 & 350 & $N T^{a}$ & 5-7.5 \\
\hline SB12 & ANSB12-W-04976 & $31.5-41.5$ & $7 / 22 / 97$ & 17.7 & 7.03 & 987 & 275 & 2 & 15 \\
\hline \multicolumn{10}{|c|}{ June 1998 Monitoring } \\
\hline MW1S & ANMW01S-W-04990 & $44-54$ & $6 / 24 / 98$ & 16.1 & 7.07 & 1,440 & 300 & NT & 25 \\
\hline MW1D & ANMW01D-W-04988 & $130-140$ & $6 / 24 / 98$ & 14.9 & 7.17 & 662 & 275 & NT & 7.5 \\
\hline MW2S & ANMW02S-W-04991 & 49-59 & $6 / 24 / 98$ & 15.0 & 7.09 & 1,280 & 360 & 0 & 50 \\
\hline MW2D & ANMW02D-W-04993 & $129-139$ & $6 / 24 / 98$ & 14.0 & 7.39 & 765 & 350 & NT & 5 \\
\hline MW3S & ANMW03S-W-04995 & $38-48$ & $6 / 24 / 98$ & 12.9 & 7.27 & 919 & 350 & 0 & 10 \\
\hline MW3D & ANMW03D-W-04994 & $104-114$ & $6 / 24 / 98$ & 13.6 & 7.45 & 679 & 210 & NT & 7.5 \\
\hline SB01 & ANSB01-W-04987 & 118.9-128.9 & 6/23/98 & 24.2 & 7.6 & 474 & 350 & NT & 7.5 \\
\hline SB11 & ANSB11-W-04996 & $107-127$ & $6 / 25 / 98$ & 14.3 & 7.01 & 654 & 300 & NT & 5 \\
\hline SB12 & ANSB12-W-04986 & $31.5-41.5$ & $6 / 23 / 98$ & 15.6 & 6.99 & 845 & 350 & NT & 25 \\
\hline
\end{tabular}

a NT, sample not tested for dissolved oxygen. 


\section{Appendix A:}

\section{Quality Control for Monitoring at Agenda}

Quality assurance/quality control (QA/QC) for sample collection and handling activities during the Agenda monitoring investigation was tracked by the collection of field blanks, equipment rinsates, and trip blanks. Sample integrity throughout the collection, shipping, and analysis activities was monitored by the use of custody seals and chain-of-custody records. Duplicate samples were analyzed for carbon tetrachloride and chloroform at different analytical laboratories, with different analytical methods, to provide a measure of analytical accuracy and precision. The two analytical methods were as follows.

1. U.S. Environmental Protection Agency (EPA) Contract Laboratory Program (CLP) methodology, based on the EPA CLP SOW OLM03. The QA/QC procedures followed included initial and continuing calibration of instruments, analysis of laboratory blanks, monitoring of surrogate spike recovery, and matrix spike/matrix spike duplicate analyses. Concentrations were reported above a quantitation limit of $5 \mu \mathrm{g} / \mathrm{L}$.

2. EPA Method 524.2 (purge-and-trap method with a gas chromatograph-mass spectrometer system). In this method, the concentration was calculated by comparison of the mass spectrometer response for the quantitation ion to the response for corresponding calibration curves and/or internal standards. The internal standard recovery limits were $80-120 \%$. Calibration checks were required to be within $\pm 20 \%$ of the standard. Concentrations were reported above a quantitation limit of $2 \mu \mathrm{g} / \mathrm{L}$.

\section{July 1997 Monitoring}

In July 1997, samples were analyzed at Intertek Testing Services, Colchester, Vermont, with EPA CLP methodology. Three of the 9 groundwater samples were also analyzed at the Applied Geosciences and Environmental Management (AGEM) Laboratory at Argonne with EPA Method 524.2. Comparable results were obtained at both laboratories for the two samples in which carbon tetrachloride was detected. For these samples, the calculated relative percent 
difference (RPD) value between ITS and AGEM Laboratory results was less than 31\%. Chloroform was not detected in the samples at either laboratory.

\section{June 1998 Monitoring}

In June 1998, groundwater samples were analyzed at AGEM Laboratory with EPA Method 524.2. Four of the 9 samples were also analyzed at Southwest Laboratory, Broken Arrow, Oklahoma, with EPA CLP methodology. Comparable results were obtained at both laboratories for the two samples in which carbon tetrachloride was detected. For these samples, the calculated RPD value between ITS and AGEM Laboratory results was less than 38\%. Chloroform was not detected in the samples at either laboratory. 